\title{
One Small Municipality and Future of Renewable Energy Strategy
}

\section{Aleksandar Valjarević ${ }^{1,2 *}$, Dragana Valjarević ${ }^{3}$, Dejan Filipović ${ }^{4}$, Jovan Dragojlović ${ }^{5}$, Saša Milosavljevićc ${ }^{5}$ Miško Milanović ${ }^{4}$}

${ }^{1}$ Department for Management of Science and Technology Development, Ton Duc Thang University, Ho Chi Minh City, Vietnam

${ }^{2}$ Faculty of Environment and Labour Safety, Ton Duc Thang University, Ho Chi Minh City, Vietnam ${ }^{3}$ University of Priština-Kosovska Mitrovica, Faculty of Sciences, Department of Mathematics, Ive Lole Ribara 29, 38220 Kosovska Mitrovica, Serbia

${ }^{4}$ University of Belgrade, Faculty of Geography, Studenstskitrg 3/III, 11000 Belgrade, Serbia ${ }^{5}$ University of Priština-Kosovska Mitrovica, Faculty of Sciences, Department of Geography, Ive Lole Ribara 29, 38220 Kosovska Mitrovica, Serbia

Received: 10 March 2020

Accepted: 14 May 2020

\begin{abstract}
The subject of this paper is to present an investigation of renewable energy potential in one small municipality in south Serbia. Serbia has a relatively small area but a large number of renewable energy resources. This energy is divided into solar, wind, geothermal and waste wood. One municipality on the south east has very large potential for the renewable energy utilization. The municipality of Kuršumlija has an area of $952 \mathrm{~km}^{2}$ but with poor dense of the population. In this municipality we have one of the most powerful resources of the renewable energy, estimated on 118.5 MWt. With the help of different methods such as GIS (Geographical Information System), numerical and geo-statistical analyses, were analyzed total capacity of the renewable energy. Other relevant documents are the municipality strategy documents, satellite recordings, cadaster data, analogue plans and maps. The estimated capacity of geothermal energy with included 23 springs may reach $25.5 \mathrm{MWt}$. The waste wood estimated capacity is may reach $1123.5 \mathrm{TJ} /$ year or $35.6 \mathrm{MWt}$. The solar potential may reach $1810.8 \mathrm{Tj} /$ year or $57.4 \mathrm{MWt}$. The main goal of this research is to present renewable energy potential of the municipality and compare it with dirty kinds of energy. Other goals are to present benefits and advantages of the utilization of renewable energy sources. This research is also important to present to the broader readership and it can be the start initiative for deeper investigation of renewable energy resources.
\end{abstract}

Keywords: municipality of Kuršumlija, solar, waste wood, geothermal, cost of energy

*e-mail: aleksandar.valjarevic@tdtu.edu.vn 


\section{Introduction}

The territory of Serbia covers the area of $88,407 \mathrm{~km}^{2}$. Serbia belongs to the central-east Europe and central Balkan Peninsula [1]. The position of Serbia with energy resources gives plenty of possibilities for future development. The main problem presents very low energy efficiency, especially in the south-east part of the country [2]. The economy of Serbia still depends on dirty kind of energy resources, imported from the Russian Federation and Arabian countries such as oil or natural gas. Some of the energy resources are produced in the territory of Serbia such as timber, coal and a small part of the oil. In the process of negotiations with the EU (Europe Union), Serbia must make a better use of renewable energy. All sources of dirty energy in the country must be reduced by $20 \%$. Renewable energy resources must grow by $30 \%$ until 2050 . This relative ambitious plan will include renewable energy resources in the country such as wind and solar energy. The EU set up many grants for that. In this strategy was included climate change effect [3, 4]. In most EU countries laws proposed $20 \%$ reduction of the dirty kind energy resources by 2020. The EU tries to improve energy efficiency, the balance of the energy cost and reduce import of natural gas [5-9], the global scale, energy transition must be taken very seriously. Researchers and Governments concluded that the energy-related to $\mathrm{CO}_{2}$ emissions increase by $6 \%$ from 33Gt in 2015 to $35 \mathrm{Gt}$ in 2050. If would be Paris Agreement applied emission may drop down for 9.7Gt until 2050. This will be important for stopping of temperature increase for $2.0^{\circ} \mathrm{C}$. In any case, the necessity for energy in the world would rise by $14 \%$ until 2020 and $63 \%$ until 2050 . Before 2050, almost 120 trillion USD must be invested in the energy sector around the world. The renewable energy sector would increase by 52 trillion USD. Additionally, 11.6 million jobs in the energy sector will be realized until 2050 [10]. In the modern world, there are slight differences between rural and urban areas in the production of renewable energy [11]. In practical way it is necessary to test estimation of coast and power of renewable energy resources. We have some opposite conclusions about coast and value of renewable energy. The researchers in one research used the Driscoll-Kraay estimator to conclude if renewable energy better that non-renewable energy. The researchers who concluded that renewable energy have not always contributed with economic growth, as well as non-renewable energy usually contributed to economic growth [12]. Today, renewable energy sources supply $14 \%$ of the total world energy demand UNDP (United Nations Development Program). The volume of renewable energy is expected to increase significantly between $30-80 \%$ to 2040 . The production of geothermal energy (equivalent to oil tones in millions) in 2020 is predicted to $186 ; 333$ in 2030, and respectively 493 in 2040 [13]. In one of the most powerful countries. The United States production of the renewable energy is only $3 \%$. This low use of renewable energy was connected with different social, economic and technical barriers in the United States, as well as wind, solar, biomass, geothermal, and hydroelectric power sources are still not embraced enough [14]. Some of the researches try to explain the relationship between tariff and the real cost of energy derived from renewable energy resources [15]. Even if renewable energy resources would be doubled in the present century, it still can't replace energy from fossil fuels. In the next year in Serbia has expected slowly transition in the energy sector.

\section{Materials and Methods}

\section{Study Area}

The position of the municipality of Kuršumlija gives enough possibility for future development. The municipality has a south-east position in the territory of Serbia, the territory covers an area of $952 \mathrm{~km}^{2}$ [16]. Kuršumlija has 90 settlements with 19,213 inhabitants in total, but most of the settlements are without or with a small number of citizens [17]. There are three official spas in the municipality, spa of Kuršumlija, the spa of Prolom and spa of Lukovo. The municipality is a mountain-hilly area with average altitudes between 300-1700 with deep forest, the deepest in the country. The main settlement presents town of Kuršumlija located in the mouth of the Banjska river to the Toplica river. In the municipality, there are three spas. All spas have hyper-thermal waters. With 23 thermal-mineral springs, the municipality contains big geothermal energy potential. After the $60 \mathrm{~s}$ all thermal-mineral springs reopened for use. The mineral waters into spas are one of the most attractive in Europe and with curative effects. The outlet temperatures in the spas ranges between $37^{\circ} \mathrm{C}$ and $87^{\circ} \mathrm{C}$. The thermal-mineral waters contain the alkaline earth elements and in one litre there are $315 \mathrm{~cm}^{3}$ of $\mathrm{CO}_{2}$. Water discharge in the springs varies between $4 \mathrm{l} / \mathrm{s}$ to $70 \mathrm{l} / \mathrm{s}$. The spa of Prolom has the nitrogenous, medium alkaline water with ( $\mathrm{pH}$ 8.4). This waster is also low mineralized waters with contents of (337-441 mg/l), natrium, hydrocarbonate, silicon hypo-thermal waters. These waters are (sulphuric, carbon-acidic, alkaline, and with a huge content of iron). The total estimated potential of geothermal energy in the three spas are 4.64 MWt [18-23]. Excluding municipality of Kuršumlija the area with big geothermal potential is Kopaonik mountain [24]. The municipality of Kuršumlija is situated in the part of the Republic of Serbia rich in the forest. However, the density of forest was not equal through the time. In 2013 forest covered the area of $676.76 \mathrm{~km}^{2}$. In 1953 the forest-covered almost $68 \%$ of the territory, in 1987 was $67 \%$ in 2013 was $70 \%$. increase. Owing to the changes that characterize this region such as depopulation, migrations, and urbanization, the forests have increased their number 


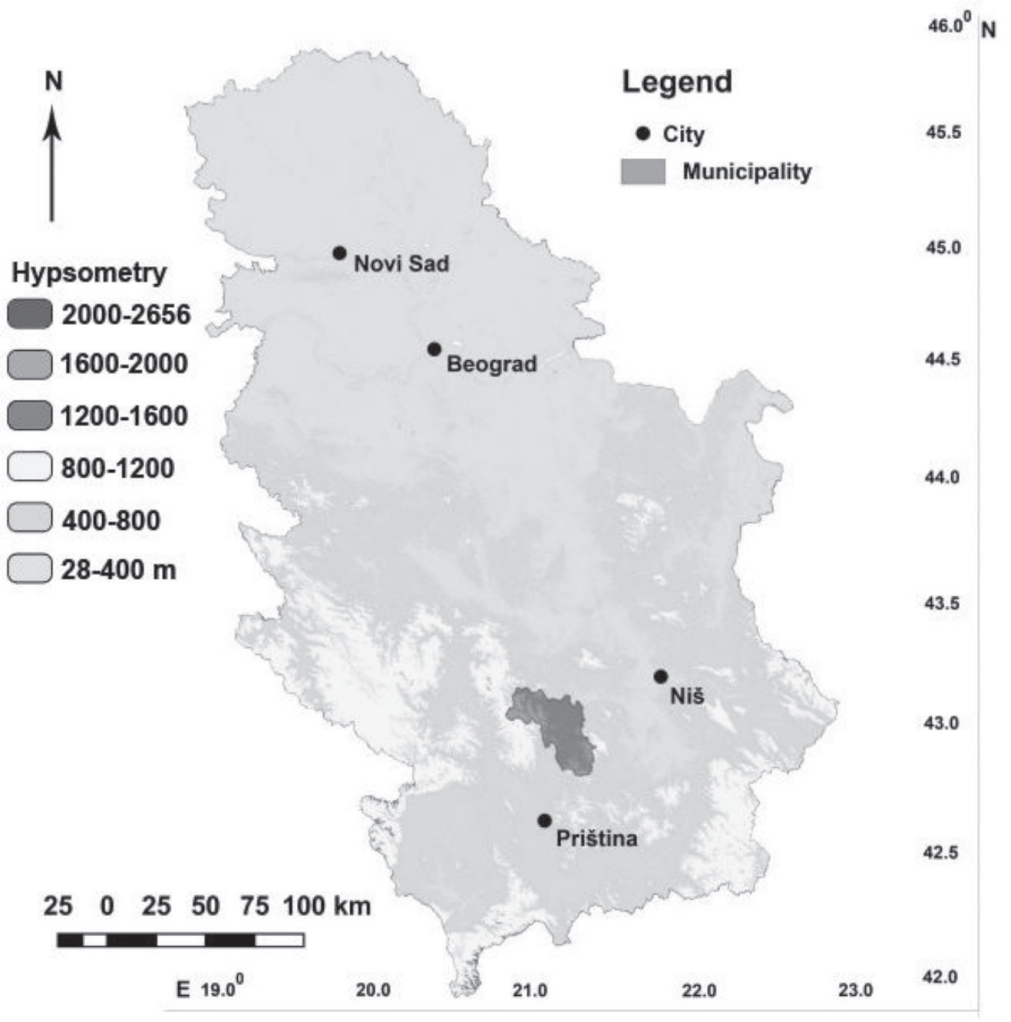

Fig. 1. Position of the municipality of Kuršumlija.

after 2000. In the municipality has a different species of trees. The most common are Oak, Beech, Pine and Fir (Fig. 4). The Moderate-Continental climate type according to the Köppen classification is dispersed around the country. Spatial distribution of climate parameters is caused by geographic location, relief and local influence as a result of a combination of relief, distribution of air pressure, terrain exposition, presence of river systems, vegetation, urbanisation etc. Among geographic characteristics and the synoptic situations significant for weather and climate of Serbia the following should be mentioned: The Alpes, the Mediterranean Sea and Genoa Bay, Panonia plain and the valley of the Morava, the Carpathian and Rodopi mountains as well as hilly-mountainous part with ravines and highland plains. The average annual air temperature for the areas higher of $300 \mathrm{~m}$ is $10.9^{\circ} \mathrm{C}$. For altitudes between 300 to $500 \mathrm{~m}$ is $10.0^{\circ} \mathrm{C}$ as well for altitudes higher of $1000 \mathrm{~m}$ is $6.0^{\circ} \mathrm{C} .80 \%$ of the areas in the municipality are between 800 and $1200 \mathrm{~m}$ of altitude, this climate type is moderatemountain. The areas higher of $1400 \mathrm{~m}$ of altitude covers $15 \%$ of the territory in the municipality. The area higher of $1600 \mathrm{~m}$ covers $5 \%$ of the territory. The main characteristics of these climates types are snowy and cold winters and chilly and short summers. With overcast lower of $52 \%$ and sunshine $1776 \mathrm{~h}$ per year, it would be useful to install new solar fields across the municipality. Serbia has big solar potential in the south and east. Which be used more in the future [25].

\section{GIS Methods for the Analysis of Geothermal Potentials}

In this research, the Geographical Information System was used for calculating renewable energy potentials. GIS and special numerical analysis were applied in the renewable data processing. All geospatial data can be used for mapping end estimating of energy potentials. In the end, the total capacity for all geothermal springs was successfully estimated. With the help of GIS analysis, all thermal-mineral springs were digitized. Global and ordinary kriging methods were employed through (QGIS) and SAGA (GIS). Using the same kriging method, the map of the average potential thermal power in MWt in the territory

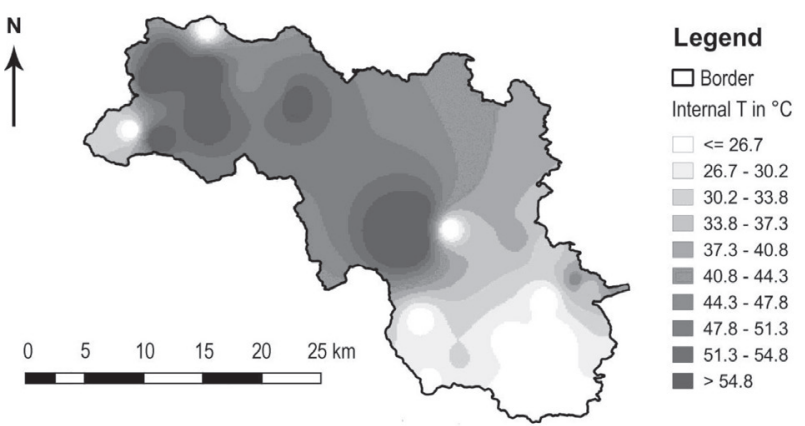

Fig. 2. Dispersion of inlet temperatures in the municipality of Kuršumlija, data was obtained from all thermal-mineral springs. 


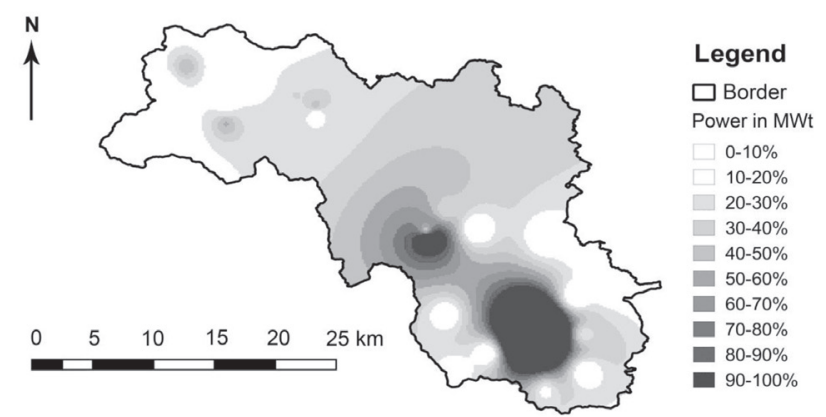

Fig. 3. Average geothermal energy and potential in MWt of the municipality of Kuršumlija.

of Kuršumlija municipality was made (Fig. 2; Fig. 3). With the help of remote sensing methods and procedures, we investigated satellite recordings of $30 \mathrm{~m}$ of the resolution.

\section{GIS Methods for the Analysis of Waste Wood Potentials}

For determining the forest density, pixel and subpixel swapping methods were used. These methods were established to determine fine resolution on the maps. This sub-pixel swapping method may predict linear features with precise determinations of the coordinates in each pixel (Eq. 1) [26, 27].

$$
W_{i, j}=\sum_{k=1}^{M} \operatorname{fraction}_{k}^{j} \times \operatorname{dist}_{i, k}^{-r}
$$

...where, $W_{i, j}$ is attractiveness of sub-pixel (i), to class ( $j$ ), $\mathrm{M}$ number of neighbouring pixels, fraction ${ }_{\mathrm{k}}^{\mathrm{j}}$ proportion of the neighbouring pixel (k) per class (j), dist ${ }^{-r}$ inverse distance weighting function between sub-pixel (i) and neighbouring pixel (k).

Very similar but generalized method was established to find soft pixels and sub-pixels (Eq.2) [28].

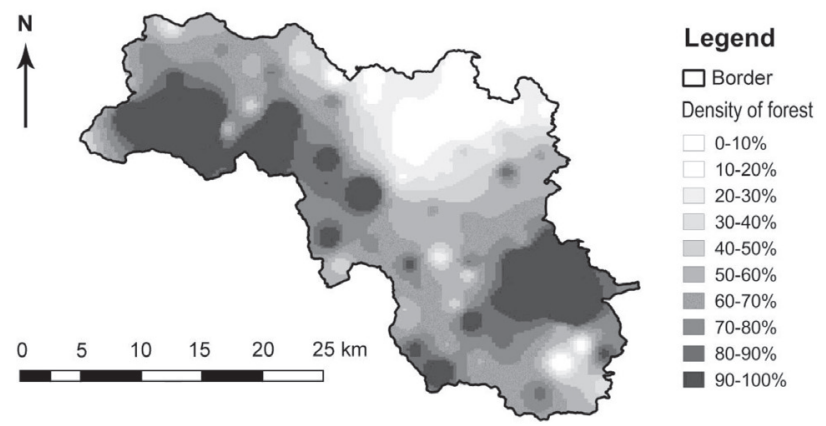

Fig. 4. Dispersion and density of forest in the municipality of Kuršumlija according to the situation from 2018.

$$
\lambda_{\mathrm{ij}}=\frac{1}{\mathrm{~h}_{\mathrm{ij}}}
$$

...where is $\left(h_{i j}\right)$ is a distance between the pixel $x_{i}$ and the neighbour pixel $x_{j}$. In our example, a similar soft combined sub-pixel method is applied to the remote sensing data. We analyzed forest density with specially created method. This method was called a sub-pixel contrast ratio method. After that QGIS and SAGA software was used with the special algorithm called Historical for detecting forest. In this algorithm filter, map parameters were established. GIS and data modelling in combination with a sub-pixel and pixel analysis are very powerful tools for calculating and describing some properties of forest data within an area. GIS software QGIS and SAGA, with the tools for geospatial calculations may give satisfactory results [29]. In this research ordinary and semi-ordinary kriging were employed with the support of Quantum Geographical Information System and SAGA (GIS). The main algorithm is Extension of Spatial Analyst. Although there are a few other methods, the priority is given to the ordinary and semi-kriging because it includes autocorrelation and the statistical relationship among the measured points. In this algorithm, the weights are based not only on the distance between the measured points and the predicted location but the overall spatial arrangement of the measured points. Additionally, it minimizes the variance of the error of estimation and gives the possibility to made semivariogram.

\section{GIS Methods and Procedures for the Analysis of Solar Potentials}

With special numerical and spatial analysis, the most suitable location for the potential installation of solar panels and power plants throughout the Municipality was established. In that case we used Digital Elevation Model (DEM) of Landsat Imagine Satellite program. The useful locations were used with the support of multi-criteria GIS analysis. In this analysis elements such as inclination, solar ecliptic was implemented [30, 31]. With specially created grid and with included length of sunshine. Potential insolation of the municipality of Kuršumlija was calculated using special grid extension in the open-source QGIS software (Fig. 5). Different planning methods and procedures may be used in the workflow to determine renewable energy resources and potentials. The main algorithms belong to multi-criteria, matrix and assessing the weights. There are a few multi-criteria methods which were used to analyze the energy potential. Some of them are ELECTRE (Elimination et Choix raduisant la Realité), AHP (the Analytic Hierarchy Process), PROMETHEE (the Preference Ranking Organization Method for Enrichment Evaluation), RASTERIZATION (Rasterization and Pixelization of the object-oriented data) [32]. Analytic Hierarchy Process (AHP) consists 


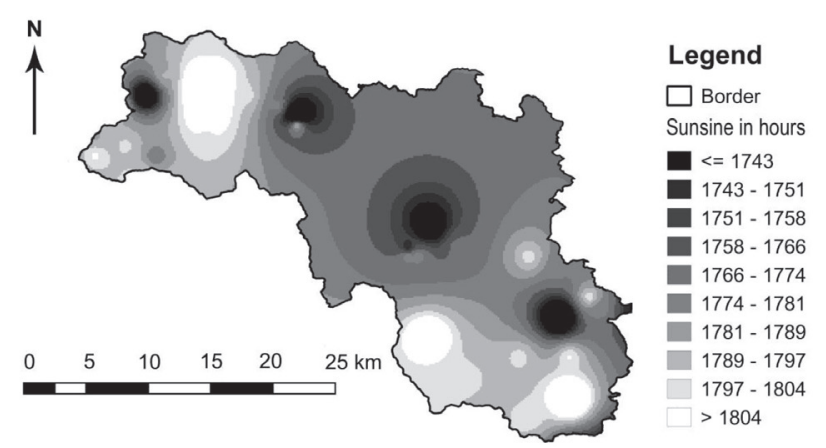

Fig. 5. Dispersion and solar potential in the municipality of Kuršumlija in hours per year.

of several steps in making the final decision. AHP is a theory of measurement for dealing with quantifiable and or intangible criteria. The main principle of decision making in AHP is that the experience and knowledge of researchers are at least as valuable as the data they use $[33,34]$. In combination with other methods such as numerical and kriging results gives satisfactory results. For geospatial calculations there are a few methods, priority is given to ordinary, semi and global kriging methods. The advantage of these methods is because it includes autocorrelation of the statistical relationship among the measured points and is very flexible in the presentation of renewable potential and distribution. (Fig. 5).

\section{Results}

\section{The Energy of the Geothermal Potentials}

The estimated total capacity of geothermal energy in the municipality of Kuršumlija is $620.36 \mathrm{TJ} / \mathrm{yr}$ or 25.5 MWt. Comparing the obtained data for the Kuršumlija municipality with those for the Pannonian Basin (which represents $24 \%$ of the territory of Serbia) and yields the total geothermal energy of $80 \mathrm{MWt}$, it is obvious that the obtained value represents almost $25 \%$ of the potential of the Pannonian Basin although the studied area is 23 times smaller and makes only $1 \%$ of the territory of Serbia. This energy could be higher because some boreholes haven't been investigated yet. This installed power may reach $25 \mathrm{MWt}$. In the future, new research must determine the total capacity of geothermal energy (Fig. 2; Fig.3).

\section{The Energy of the Waste Wood}

In the municipality, Beech covers the area of 42.1\%, Oak 43.2\%, Fir $0.7 \%$ and Pine $1.2 \%$. After GIS and remote sensing analysis, the area of forest and the number of trees were calculated. In 2018 the number of trees is $106,100,000$ or 1114.5 per hectare. An average number of trees in densest areas of the Municipality is $111,449.5$ per $\mathrm{km}^{2}$. This number shows
$25 \%$ more tress in comparison to the country and $14 \%$ in comparison to Europe. The dispersion of the forest is not equal in the municipality. The north-west territory has the densest areas of forest. After that south part of the territory has areas with deep forest. The average numbers of cut down trees per year were 650,000 . If the average volume of the cut-down tree is $1.3 \mathrm{~m}^{3}$, the annual volume will be $845,000 \mathrm{~m}^{3}$. According to the last census of the municipality, the average number is 33.8 trees or $44 \mathrm{~m}^{3}$ per inhabitant. During the sixty-five-year period, the densest area in Kuršumija covered the territory of $300 \mathrm{~km}^{2}$. The most degraded areas in 2018 cover $34 \mathrm{~km}^{2}$. In the municipality, Oak and Beech's trees present the most powerful resource of renewable energy. Production of biomass and waste wood may be successful in a micro and macro way. The average bulk density of oak in the dried state is $750 \mathrm{~kg} / \mathrm{m}^{3}$ with the average calorific power of $14,444.46 \mathrm{~kJ} / \mathrm{kg}$ [35-38]. Calorific power of dried oak is obtained from the product of average volume trick weight and a verage calorific power, therefore caloric power of $1 \mathrm{~m}^{3}$ of dried oak is $14,444.46 \mathrm{~kJ} / \mathrm{kg} \quad$ x $750 \mathrm{~kg} / \mathrm{m}^{3}=10,833,345 \mathrm{~kJ} / \mathrm{m}^{3}$. The average calorific power of wood briquettes with $12-15 \%$ humidity is $21,683.48 \mathrm{~kJ} / \mathrm{kg}$. The total calorific power is $3.300 \mathrm{t}$ of briquettes. Equivalent heat for $1 \mathrm{~m} 3$ of oak wood is $6605.1 \mathrm{t}$, and the value derived from the ratio of the total calorific power of $3.300 \mathrm{t}$ of briquettes and the average calorific power $1 \mathrm{~m}^{3}$ of dried oak. The average bulk density of beech in the dried state is $720 \mathrm{~kg} / \mathrm{m}^{3}$ with the average calorific power of wood briquettes with $11-13 \%$ humidity is $20,456,78 \mathrm{Kj} / \mathrm{kg}$. The total calorific power is $3300 \mathrm{t}$ of briquettes. This heat energy for $1 \mathrm{~m}^{3}$ of beech is 6305.2 t. In total two common species give average energy of $21,070.13 \mathrm{Kj} / \mathrm{kg}$. $25.5 \mathrm{~m}^{3}$ of both trees converted to the briquettes and renewable energy would be enough for heating one household for more than seven months with temperatures of $20^{\circ} \mathrm{C}$. The main problem presents the fact that the population in the municipality takes raw cut down trees with a very high content of humidity between $30-40 \%$. In that way loss of energy would be more than 70\%. (Fig. 4). The municipality of Kuršumlija will struggle to actively spread ecological consciousness within the population. In this study, we contribute to the development of a digital baseline which could show the relationship of various factors affecting the dispersion and quality of forests. A realistic forest management approach should be aimed at presenting a sustainable and planned tree harvest without damaging the region's forests. Use of renewable energy may be very important in future saving of forest and for better management of the local government.

\section{The Energy of the Solar Potential}

With the annual average of 2300 sunshine hours, Serbia is rich with the solar potential. The 
radiation intensity is one of the highest in Europe. During January, in the north part of the Republic of Serbia the average solar radiation intensity ranges from $1.1 \mathrm{kWh} / \mathrm{m}^{2} / \mathrm{day}$, and in the South is up to $1.7 \mathrm{kWh} / \mathrm{m}^{2} /$ day. Average solar irradiation on the territory of the Republic of Serbia ranges from $1.1 \mathrm{kWh} / \mathrm{m}^{2} /$ day on the north to $1.7 \mathrm{kWh} / \mathrm{m}^{2} /$ day on the south during January and from $5.9 \mathrm{kWh} / \mathrm{m}^{2} /$ day to $6.6 \mathrm{kWh} / \mathrm{m}^{2} /$ day during July. On a yearly basis, the average value of the global solar irradiation for the territory of the Republic of Serbia ranges from $1200 \mathrm{kWh} / \mathrm{m}^{2} /$ year in Northwest Serbia to $1550 \mathrm{kWh} / \mathrm{m}^{2} /$ year in Southeast Serbia, while in the middle part it totals to around $1400 \mathrm{kWh} / \mathrm{m}^{2} /$ year (Fig. 5). Due to this fact, Serbia has favorable conditions for the use of solar energy and its conversion into thermal and electrical energy [39-42].

\section{Discussion}

The last declaration of the Serbian assembles included new strategy for stimulation of green or renewable energy resources. This strategy law was established in 2009, but results are still very poor in an economic sense. In 2013 Serbia voted Europe Union electric energy system. Also, Serbia tries to reach 1.1 GWT until 2020. Serbia has 55 mini hydro-power plants, 97 solar plants, five bioenergy plants and only 1 small wind power plant. These renewable energies in 2019 could reach only $55 \mathrm{MWt}$, it's still presented a very small packet of planned renewable energy. The main goal for the Serbian government must be to make $27 \%$ of total energy-producing before 2020 . The one challenge will be in producing green energy from organic waste. One of the main disadvantages is on the minor exploration of geothermal energy. This energy present very big potential especially in the south-east territory. Electric energy derived from hydropower will cost 12.6 Euro/cents/Kwh. This energy until 2030 may cost more than 15 Euro/cents/Kwh. But this price will be limited to energy systems smaller of $200 \mathrm{KWh}$, next category smaller of $500 \mathrm{KWh}$ may reach the cost of 13.993 Euro/cents/Kwh. The category of $1 \mathrm{MWt}$ will have a price of 10.6 Euro/cents/Kwh. 10.944 Euro/cents/Kwh for the category of $10 \mathrm{MWt}$, for the category of $30 \mathrm{MWt}$ price will be 10.994 Euro/cents/Kwh. For a very big system of $30 \mathrm{MWt}$ price will be $7.5 \mathrm{Euro} / \mathrm{cents} / \mathrm{Kwh}$. The limit for electric energy bought from the system of $30 \mathrm{MWt}$ is 5000 hours per year of stimulation. Power plants on waste wood may produce 8600 hours per year. The biopower plants under $1 \mathrm{MWt}$ may except 12,6 Euro/cents/Kwh, bigger of $10 \mathrm{MWT}$ be stimulated with 8,22 Euro/cents/Kwh. For power plants on biogas, the estimated price will be between 15,0 and 16,11 Euro/cents/Kwh with a maximum production of 8600 hours per year of stimulation. For the power plants which used renewable energy from landfill, the price will be 8.44 Euro/cents/Kwh. For wind power plants the price will be 9.2 Euro/cents/Kwh with maximum stimulation of 9000 hours per year. Solar power wind will have the stimulation of 1400 hours per year, with the stimulated price of 9 Euro/cents/Kwh to 14.6 Euro/cents/Kwh under $1 \mathrm{MWt}$ $[43,44]$ The maximal calculated time for power plants of geothermal energy is 8600 hours with the price of 8.2 Euro/cents/Kwh. The production of combined renewable energy sources will be stimulated with the price between 7.46 and 8.2 Euro/cents/Kwh. The production of geothermal energy in Serbia has to be changed. According to some researchers, the total capacity in the whole territory of Serbia the geothermal energy is estimated between $80 \mathrm{MWt}$ and $120 \mathrm{MWt}$. The solar energy is estimated between $250 \mathrm{MWt}$ and $400 \mathrm{MWt}$, whereas the energy of waste wood is estimated between $110 \mathrm{MWt}$ and $250 \mathrm{MWt}$. For the increase of use of renewable energy resources, it would be necessary to establish better education and strong government campaign $[45,46]$. Another important factor is energy cost. The energy cost of renewable energy resources especially in Europe is still expensive and usually donated by the governments [47]. In the German energy market, two methods for estimation of energy cost were applied. The first method is the Levelized Cost of Energy (LCOE) and the second is the Energy System Analysis (ESA) method. These methods could be successfully applied to renewable energy resources [48]. In Germany, some local municipalities such as Brandenburg wants in future support $100 \%$ renewable energy policies in hope to derive more clean and safe energy [49]. Renewable energy would be the most important in rural parts of the world [50] In Africa, these areas present huge populated regions and home to the majority of the population. For producing electricity from renewable energy sources it would be necessary to established renewable portfolio standards. The total annual sum of global irradiation per square meters received by the optimally inclined fixed solar panels of $1 \mathrm{MW}$ ranges from $1390 \mathrm{KWh}$ in Sombor to $1670 \mathrm{KWh}$ in Djakovica and in Kuršumlija is 1490 KWh. In Serbia, there are more than 120 thermo-mineral springs. The average geothermal capacity in Serbia is estimated between $100 \mathrm{~mW} / \mathrm{m}^{2}$ to $120 \mathrm{~mW} / \mathrm{m}^{2}$. In Serbia, most of the geothermal energy sources are used in space heating, bathing and swimming, agricultural drying, greenhouses, farming, etc. The distribution of the geothermal energy is the highest in the areas of near the spas. The distribution of $80-100 \%$ of the geothermal energy covers the territory of $12.9 \mathrm{~km}^{2}$ (Fig. 2; Fig. 3). With the improvement of geothermal pipes, this energy can be used by more than 1200 household for heating. The temperature of $21^{\circ} \mathrm{C}$ may be equal all year and could be used for heating by winter and cooling in summer. Also, this geothermal energy may give more than $1500 \mathrm{~kW} / \mathrm{h}$ per year and save 800,000 EUR. Waste wood using of energy would save in the municipality 500,000 EUR and solar energy 800,000 EUR. That present $15 \%$ of the operating 
budget of the municipality per year. With investing in 4,000,000 EUR of new renewable energy sources until 2030 this number may reach 5,000,000 EUR per year or almost $35 \%$ of the budget. Local government can employ more than 1000 new workers in energy sectors, it is present $15 \%$ of the population [51]. The renewable resources in combination with others would be used for producing electricity. With the help of the EU strategy, this very poor and undiscovered region may get huge development if be included renewable energy potentials in the municipality strategy. In that way, external migration may be stopped and redirected in the future ecological parts of the municipality. Also, the salary would be increased by $20 \%$ in the next decades, according to the development of the energy sector. This is will be more successful in wood and tourism sectors.

\section{Conclusion}

The municipality of Kuršumlija covers a relatively small area of $952 \mathrm{~km}^{2}$, but the number of renewable energy resources is very large. The inside temperatures in the spas are between $20^{\circ} \mathrm{C}$ to $72^{\circ} \mathrm{C}$. The municipality has three spas Kuršumlijska $\left(68^{\circ} \mathrm{C}\right)$, Lukovska $\left(67^{\circ} \mathrm{C}\right)$ and Prolom $\left(31^{\circ} \mathrm{C}\right)$. The total number of thermomineral springs is 23 . From 22 thermo-mineral springs with temperatures higher than $20^{\circ} \mathrm{C}$, it is possible to get renewable energy resources. Today the use of geothermal energy is $0.8 \mathrm{MWt}$ and this energy is used for heating in two hotels in the Lukovska spa. This energy presents only $3.13 \%$ of the total energy. The municipality has a large area of forest with 1106 trees average per hectare, estimated areas of forest land are $70 \%$. In some parts of the municipality, this area is larger than $85 \%$. In present time waste wood energy isn't supported with any kind of energy plants. In future, the building of three energy plants with waste wood is planned. The installed power may reach $2 \mathrm{MWt}$. Even if these plants were installed this energy would present only $5.6 \%$. The most useful parts in the municipality are located in the west and south. The solar potential is very big too. GIS analysis of relief in the Municipality showed that only $35 \%$ of the territory has these results. Southwest territories have a sunshine duration of $1804 \mathrm{~h}$ and more. In this area, there is one plant of solar panels with an installed power of $1 \mathrm{MWt}$. In the east area of the Municipality, one small solar plant with installed energy of $0.3 \mathrm{MWt}$ was installed. The total installed power of solar energy is $1.5 \mathrm{MWt}$. Today this installed energy presents only $2.6 \%$. The present use of renewable energy resources is very low, less than $3 \%$. In 2050 this number would be probably 7\%. The nonrenewable resources still make the main energy in the Municipality. The $50 \%$ in the total budget of energy belongs to the energy from thermal power stations, $40 \%$ belongs to hydropower plants and $10 \%$ to energy derived from oil and natural gas. The total potential of renewable energy resources may supply more than 3000 households in the municipality of Kuršumlija with renewable and clean energy. This energy can reduce the negative implications of dirty and non-renewable energy resources. According to changing prices of dirty energy resources, more than 2,000,000 EUR would be saved per year. Another benefit of clean energy will be in saving natural resources. The first estimation of actual salary which is only 300 EUR per month, will be doubled if the municipality invests to new renewable energy sources. In that case, we may except revitalization of the municipality in real sense. Another benefit would be future membership in the Europe Union, especially because the Europe Union want to invest in the renewable energy sector. This research would be the initial base for new general research of the whole territory of the Republic of Serbia.

\section{Acknowledgement}

The authors are very grateful to the municipality of Kuršumlija for the very important data within this research.

\section{Conflict of Interest}

"The authors declare no conflict of interest".

\section{References}

1. VALJAREVIĆ A., SREĆKOVIĆ-BATOĆANIN D., VALJAREVIĆ D., MATOVIĆ V. GIS-based method for analysis of a better utilization of thermal-mineral springs in the municipality of Kursumlija (Serbia). Renewable and Sustainable Energy Reviews, 92, 948, 2018.

2. MILOJEVIC M., MARTINOVIC M. Geothermal Energy Possibilities, Exploration and Future Prospects in Serbia. Proceedings World Geothermal Congress Antalya, Turkey, 24-29, 2002.

3. NAGY K., KÖRMENDI K. Use of renewable energy sources in light of the "New Energy Strategy for Europe 2011-2020". Applied Energy, 96, 393, 2012.

4. GOLUSIN M., MUNITLAK-IVANOVIĆ O., BAGARIĆ I., VRANJEŠ, S. Exploitation of geothermal energy as a priority of sustainable energetic development in Serbia. Renewable and Sustainable Energy Reviews, 14 (2), 868, 2010. https://doi.org/10.1016/j.rser.2009.06.026

5. CARVALHO M.G. EU energy and climate change strategy. Energy, 40 (1), 19, 2012.

6. ATTERIDGE A., SAVVIDOU G. Development aid for energy in Small Island Developing States. Energy, Sustainability and Society, 9, 10, 2019.

7. HAMILTON C.L., BELL E., HARTTER J., SALERNO D.J. A change in the wind? US public views on renewable energy and climate compared. Energy, Sustainability and Society, 8, 11, 2018.

8. GIELEN D., BOSHELL F., SAYGIN D., BAZILIAN M.D., WAGNER N., GORINI R. The role of renewable energy 
in the global energy transformation. Energy Strategy Reviews, 24, 38, 2019.

9. SOVACOOL B.K. Rejecting renewables: The sociotechnical impediments to renewable electricity in the United States. Energy Policy, 37 (11), 4500, 2009.

10. AFONSO T.L., MARQUES A.C., FUINHAS J.A. Strategies to make renewable energy sources compatible with economic growth. Energy Strategy Reviews, 18, 121, 2017.

11. PANWAR N.L., KAUSHIK S.C., KOTHARI S. Role of renewable energy sources in environmental protection: a review. Renewable and Sustainable Energy Reviews, 15 (3), 1513, 2011

12. UNDP World energy assessment 2000 - energy and the challenge of sustainability. New York, 2000. UNDP (ISBN 9211261260).

13. FRIDLEIFSSON I.B. Geothermal energy for the benefit of the people. Renewable and Sustainable Energy Reviews, 5 (3), 299, 2001.

14. ALIZADA K. Rethinking the diffusion of renewable energy policies: A global assessment of feed-in tariffs and renewable portfolio standards. Energy Research \& Social Science, 44, 346, 2018.

15. ERKER S., LICHTENWOEHRER P., ZACH F., STOEGLEHNER G. Interdisciplinary decision support model for grid-bound heat supply systems in urban areas. Energy, Sustainability and Society, 9, 11, 2019.

16. MAĆEJKA M., TANASKOVIĆ R. Kursumlija Municipality, Tour Monograph Guide Kursumlija, 23-9, 2008.

17. VALJAREVIĆ A., DJEKIĆ T., STEVANOVIĆ V., IVANOVIĆ R., JANDZIKOVIĆ B. GIS Numerical and remote sensing analyses of forest changes in the Toplica region for the period of 1953-2013. Applied Geography, 92, 131, 2018

18. PAVLOVIĆ T.M., RADONJIĆ I.S., MILOSAVLJEVIĆ D.D., PANTIĆ L.S. A review of concentrating solar power plants in the world and their potential use in Serbia. Renewable and Sustainable Energy Reviews, 16 (6), 3891, 2012.

19. KOMATINA M. Medical geology, Tellur. Belgrade, 239-314, 2001

20. JANJIĆ M., KOMATINA M., NIKIĆ Z., TIMOTIĆ B., NEŠIĆ D., KNEŽEVIĆ T., STANOJEVIĆ S., ANDJELSKI H., BOGUNOVIC Z., KERKEZ Z. Healing waters and spas of Serbia. Novi Sad, 23, 134, 2007.

21. LAZIĆ M., FILIPOVIĆ B., JEVTOVIĆ B. Thermal mineral waters of the Lukovska spa Spas Resorts of Yugoslavia, Belgrade, 111-117, 1995.

22. MARKOVIĆ J. Spas of Yugoslavia. Globus newsletter Belgrade, 6, 1231, 1974

23. FILIPOVIĆ B., IGRUTINOVIĆ D. Hydrogeological zoning of the Republic of Serbia in terms of the formation of certain types of groundwater-aquifer. Communist Institute Jaroslav Černi, 24, 119, 1981.

24. RISTIĆ, D., VUKOIČIĆ, D., NIKOLIĆ M., MILINČIĆ M., KIĆOVIĆ, D. Capacities and energy potential of thermalmineral springs in the area of the Kopaonik tourist region (Serbia), Renewable and Sustainable Energy Reviews, 102, 129, 2019

25. PAVLOVIĆ T.M., RADONJIĆ I.S., MILOSAVLJEVIĆ, D.D., PANTIĆ, L.S. A review of concentrating solar power plants in the world and their potential use in Serbia, Renewable and Sustainable Energy Reviews, 16, 891, 2012.
26. NIROUMAND M.J., SAFDARINEZHAD A.R., SAHEBI M.R., MOKHTARZADE A.A. Novel approach to super resolution mapping of multispectral imagery based on pixel swapping technique. Melbourne, Australia: ISPRS Annals of the Photogrammetry. Remote Sensing and Spatial Information Sciences, 1-7, 2012.

27. PROTIĆ D., KILIBARDA M., NESTOROV I. Super resolution mapping of agricultural parcel boundaries based on localized partial unmixing. Geodetski List, 89, 4, 259, 2012.

28. BOSSARD M., FERANEC J., OTAHEL J. CORINE land cover technical guide addendu 2000, technical report 40 Copenhagen, Denmark: EEA, 2000.

29. WU S.T., CHEN Y.S. Examining eco-environmental changes at major recreational sites in Kenting National Park in Taiwan by integrating SPOT satellite images and NDVI. Tourism Management, 57, 23, 2016.

30. MALCZEWSKI J. GIS-based land-use suitability analysis: A critical overview Progress in Planning, 62, 1, 3, 2004.

31. PEW K.L., LARSEN C.P.S. GIS analysis of spatial and temporal patterns of human-Caused wildfires in the temperate rain forest of Vancouver Island, Canada, Forest Ecology and Management, 140 (1), 1, 2001.

32. NARVARTE L., LORENZO E. Tracking and ground cover ratio. Progress in Photo-voltaics: Research and Applications, 16 (8), 703, 2008.

33. MENTIS D., HUSSAIN SIYAL S., KORKOVELOS A. HOWELLS M. Estimating the spatially explicit wind generated electricity cost in Africa - A GIS based analysis. Energy Strategy Reviews, 17, 45, 2017.

34. Republika Srbija, Ministarstvo rudarstva i energetike, NL Agency. Akcioni plan za biomasu, 2010-2012; 2010. http:// www.ssl-link.com/mre/cms/ (accessed on 04.12.2019).

35. DIETMAR R.O. European energy law and its impact on Serbia progress, perspectives and possibilities. Thermal Science, 16 (1), 17, 2012.

36. BOHLIN F., VINTERBAOCK J., WISNIEWSKI J. Solid biofuels for carbon dioxide mitigation, Biomass and Bioenergy, 15 (4-5), 277, 1998.

37. ĐERČAN B., LUKIĆ T., BUBALO-ŽIVKOVIĆ M., ĐURĐEV B., STOJISAVLJEVIĆ R., PANTELIĆ M. Possibility of efficient utilization of wood waste as a renewable energy resource in Serbia, Renewable and Sustainable Energy Review, 16 (3), 1516, 2011.

38. SÁNCHEZ-LOZANO J.M., GARCÍA-CASCALES M.S., LAMATA M.T. Evaluation of Suitable locations for the installation of solar thermoelectric power plants. Computers and Industrial Engineering, 87, 343, 2015.

39. POTIĆ I., GOLIĆ R., JOKSIMOVIĆ T. Analysis of insolation potential of Knjaževac Municipality (Serbia) using multi-criteria approach Renewable and Sustainable Energy Reviews, 56, 235, 2016.

40. COOPER P.I. The absorption of radiation in solar stills. Solar Energy, 12 (3), 333, 1969.

41. KLEIN S.A., Calculation of monthly average insolation on tilted surfaces. Solar Energy, 19 (4), 325, 1997.

42. GOLUSIN M., TESIC Z., OSTOJIC A. The analysis of the renewable energy production sector in Serbia. Renewable and Sustainable Energy Reviews, 14 (5), 1477, 2010.

43. BOJIC M., Education and training in renewable energy sources in Serbia and Montenegro. Renewable Energy, 29 (10), 1631, 2004.

44. HANSEN K. Decision-making based on energy costs: Comparing levelized cost of energy and energy system costs. Energy Strategy Reviews, 24, 68, 2019. 
45. BUSH H., MCCORMICK K. Local power: exploring the motivations of mayors and key success factors for local municipalities to go 100\% renewable energy. Energy, Sustainability and Society, 4, 5, 2014.

46. KUMAR D., MOHANTA D.K., JAAY BHARATA REDDY M. Intelligen optimization of renewable resource mixes incorporating the effect of fuel risk, fuel cost and $\mathrm{CO}_{2}$ emission. Frontiers in Energy, 9 (1), 91, 2015.

47. TOMASZEWSKA M. Membrane Distillation - Examples of Applications in Technology and Environmental Protection, Polish Journal of Environmental Studies, 9 (1), 27, 2000.

48. TUDU B., MANDAL K.K., CHAKRABORTY N. Optimal design and development of PV-wind-battery based nano-grid system: A field-on-laboratory demonstration. Frontiers in Energy, 13 (2), 269, 2019.

49. WOCH F., HERNIK J., LINKE J.H., SANKOWSKI E., BĘCZKOWSKA M., NOSZCZYK T. Renewable Energy and Rural Autonomy: A Case Study with Generalizations, Polish Journal of Environmental Studies, 26 (6), 2823, 2017.

50. HUENTELER J., NIEBUHR C., SCHMIDT T.S., The effect of local and global learning on the cost of renewable energy in developing countries, Journal of Cleaner Production, 128, 6, 2016. 